\title{
HUBUNGAN LATAR BELAKANG BUDAYA KELUARGA DENGAN DUKUNGAN KELUARGA DALAM PENCEGAHAN PRIMER HIPERTENSI DI WILAYAH KERJA PUSKESMAS WINDUSENGKAHAN KABUPATEN KUNINGAN
}

\author{
Ronny Suhada Firmansyah \\ Sekolah Tinggi Ilmu Kesehatan Kuningan \\ ronnysuhada@gmail.com
}

\begin{abstract}
Abstrak
Kementerian Kesehatan menyatakan bahwa di Indonesia terjadi peningkatan prevalensi hipertensi dalam tiga tahun terakhir. Kabupaten Kuningan merupakan wilayah dengan prevalensi hipertensi terbanyak di Indonesia. Kasus hipertensi merupakan salah satu penyakit yang termasuk sepuluh penyakit terbesar selama tiga tahun di seluruh Puskesmas di Kabupaten Kuningan termasuk Puskesmas Windusengkahan yang memiliki catatan kenaikan hipertensi tiga tahun terakhir. Tujuan dari penelitian ini adalah untuk menentukan faktor yang paling berhubungan dengan dukungan keluarga dalam pencegahan primer hipertensi pada di Wilayah Kerja Puskesmas Windusengkahan Kabupaten Kuningan. Jenis penelitian adalah penelitian kuantitatif analitik korelasional. Responden pada penelitian ini adalah anggota keluarga usia dewasa baik pria maupun wanita di Wilayah Kerja Puskesmas Windusengkahan yang memiliki riwayat keluarga hipertensi dan memiliki minimal dua faktor dari risiko hipertensi yang bertempat tinggal bersama keluarga. Pengambilan sampel di setiap kelurahan dalam pada wilayah kerja Puskesmas Windusengkahan ini menggunakan proporsional random sampling. Hasil dari penelitian ini adalah ada hubungan antara latar belakang budaya keluarga dengan dukungan keluarga dalam pencegahan primer hipertensi. Kesimpulan perawat komunitas sebaiknya mengembangkan suatu strategi yang dapat lebih meningkatkan keluarga dalam memberikan dukungan dalam pencegahan primer hipertensi. Keluarga menjadi faktor penting bagi anggota keluarga dalam pemeliharaan kesehatannya khususnya pada pencegahan primer hipertensi.
\end{abstract}

Kata Kunci : Hipertensi, Pencegahan, Dukungan Keluarga, Budaya 
JOURNAL OF NURSING PRACTICE AND EDUCATION

VOL. 01 No. 01, DESEMBER 2020
Ciptaan disebarluaskan di bawah

Lisensi Creative Commons Atribusi-

NonKomersial-BerbagiSerupa 4.0

Internasional.

\section{Pendahuluan}

WHO (2012) menjelaskan bahwa negara yang memiliki penghasilan tinggi memiliki prevalensi hipertensi lebih kecil dari negara berkembang atau negara yang memiliki penghasilan yang rendah. Dari 927 juta penderita hipertensi di dunia, sebanyak 333 juta penderita berada di negara maju dan 639 juta penderita sisanya terdapat di negara berkembang. Hipertensi merupakan faktor penting yang mempengaruhi hampir satu miliar orang di seluruh dunia dan menyebabkan sekitar 7,1 juta kematian per tahun pada usia dewasa (Osamor, P. E., Owumi, 2011).

Menurut Huang et al., (2014) menjelaskan bahwa prevalensi hipertensi di dunia sebesar $26,4 \%$ yang terdiri dari populasi usia dewasa. Susilo, Yekti, \& Ari (2011) menjelaskan bahwa Indonesia merupakan negara dengan peringkat kelima dalam hal kejadian hipertensi di kawasan Asia Tenggara yaitu sebanyak yaitu $15 \%$ dari seluruh penduduk.

Kemenkes (2013) menyatakan bahwa di Indonesia terjadi peningkatan prevalensi hipertensi dari 7,6\% tahun 2007 menjadi 9,5\% pada tahun 2013. Di Indonesia penyakit hipertensi dan komplikasinya merupakan peringkat kelima dari sepuluh besar penyebab kematian tertinggi terhitung dari 41.590 kematian dari Januari sampai Desember 2014 (Balitbangkes, 2014).

Sesuai data dari Riskesdas (2013), bahwa Jawa Barat merupakan provinsi dengan prevalensi hipertensi paling tinggi di Pulau Jawa $(29,4 \%)$ dengan proporsi faktor risiko hipertensi pada masyarakat Jawa Barat yang menduduki peringkat atas dalam beberapa kategori. Peluang masyarakat di Jawa Barat cukup besar untuk menderita hipertensi bila tidak dilakukan pencegahan sejak dini.

Kabupaten Kuningan merupakan wilayah dengan prevalensi hipertensi terbanyak di Indonesia yaitu sebanyak 43,6 persen (Balitbangkes, 2014). Selain itu kasus hipertensi merupakan salah satu penyakit yang termasuk 10 penyakit terbesar selama 3 tahun sejak 2012 sampai 2014 di seluruh Puskesmas di Kabupaten Kuningan termasuk Puskesmas Windusengkahan yang memiliki catatan kenaikan hipertensi tiga tahun terakhir (Profil Puskesmas Windusengkahan, 2014).

Menurut Bhadoria et al., (2014) bahwa hipertensi adalah kondisi dimana seseorang mempunyai tekanan darah sistole (Sistolic Blood Pressure) lebih atau sama dengan $140 \mathrm{mmHg}$ atau tekanan darah diastole (Diastolic Blood Pressure) lebih 
JOURNAL OF NURSING PRACTICE AND EDUCATION VOL. 01 NO. 01, DESEMBER 2020
Ciptaan disebarluaskan di bawah

Lisensi Creative Commons Atribusi-

NonKomersial-BerbagiSerupa 4.0 Internasional. atau sama dengan $90 \mathrm{mmHg}$ sesuai kriteria WHO atau memiliki riwayat penyakit hipertensi sebelumnya. Wu et al., (2012) menjelaskan bahwa hipertensi menurut diagnosis WHO di Amerika Serikat adalah tekanan sistolik > $140 \mathrm{mmHg}$ dan tekanan diastoliknya $>90 \mathrm{mmHg}$.

Menurut Acelajado (2010) dan Gu et al., (2014) bahwa hipertensi akan menyebabkan serangan jantung, pembesaran pada jantung, gagal jantung, dan stroke. Menurut Suhadi (2011) bahwa kondisi seseorang yang menderita hipertensi mengalami perasaan ketidakpastian, ketidakberdayaan, dan hambatan berhubungan sosial dengan orang lain menimbulkan respon berduka. Menurut data dari BPJS (2015) bahwa penyakit hipertensi ringan merupakan penyakit dengan peringkat ke- 6 dalam pembiayaan terbesar rawat inap di Rumah Sakit selama tahun 2014 yaitu sebanyak 70.218 kasus.

Menurut Riskesdas (2013) bahwa konsumsi makanan berlemak, berkolesterol tinggi, dan gorengan, provinsi Jawa Barat ada pada peringkat ketiga tertinggi nasional $(50,1 \%)$ serta berada diatas proporsi nasional yakni 40,7\%. Menurut Sugiharto (2007) bahwa konsumsi lemak jenuh menjadi faktor risiko terjadinya hipertensi, nilai $\mathrm{p}=0,001 ; \mathrm{OR}=7,72 ; 95 \% \mathrm{CI}: 2,45$ -
24,38. Menurut Kapriana \& Sulchan (2012) dalam penelitiannya di Semarang menunjukkan bahwa asupan tinggi lemak menjadi faktor risiko kejadian hipertensi obesitik, nilai $\mathrm{p}=0,002$; $\mathrm{OR}=4,3 ; 95 \% \mathrm{CI}$ : 1,696-11,069.

Penelitian Ahmad Husain Asdie, (2009) menjelaskan bahwa orang yang obesitas memiliki risiko terkena hipertensi sebesar 2,653 kali lebih tinggi dibandingkan dengan orang yang tidak obesitas. Hasil penelitian oleh Rahayu (2012) menjelaskan bahwa orang dengan obesitas 8,449 kali lebih berisiko daripada orang yang tidak obesitas.

Dalam hal perilaku merokok, proporsi perokok di Jawa Barat mencapai $27,1 \%$, menjadi peringkat kedua nasional dan menjadi peringkat pertama di Pulau Jawa (Kemenkes, 2013). Wahiduddin \& Hasrin (2013) dalam penelitiannya menjelaskan bahwa perilaku merokok merupakan faktor risiko terhadap kejadian hipertensi, dengan $\mathrm{OR}=2,32 ; 95 \% \mathrm{CI}$ : 1,24-4,35. Menurut Martiningsih (2011) bahwa dengan nilai $\mathrm{OR}=5,318$ yaitu seseorang yang merokok memiliki resiko untuk mengalami hipertensi sebesar 5,3 kali dibandingkan dengan responden yang tidak merokok. 
JOURNAL OF NURSING PRACTICE AND EDUCATION VOL. 01 NO. 01, DESEMBER 2020
Ciptaan disebarluaskan di bawah

Lisensi Creative Commons Atribusi-

NonKomersial-BerbagiSerupa 4.0

Internasional
Untuk kategori konsumsi makanan asin, proporsi provinsi Jawa Barat sebesar $45,3 \%$, berada diatas rata-rata nasional yakni 26,2\% (Kemenkes, 2013). Menurut Muliyati et al., (2011) dalam penelitiannya menjelaskan bahwa sebanyak 93,7\% responden yang mengkonsumsi garam natrium lebih menderita hipertensi dengan nilai $\mathrm{p}=0,001$. Qin et al., (2014) dalam penelitiannya di Cina menunjukkan bahwa konsumsi garam yang tinggi berhubungan dengan hipertensi dengan nilai $\mathrm{p}=0,001$.

Wahiduddin \& Hasrin (2013) menjelaskan bahwa kurangnya aktivitas fisik yang merupakan faktor risiko yang mempengaruhi terjadinya hipertensi, dengan $\mathrm{OR}=2,67 ; 95 \% \mathrm{CI}: 1,20-5,90$. Hashani et al., (2014) dalam penelitiannya juga didapatkan hasil bahwa aktivitas fisik yang kurang juga berhubungan dengan terjadinya hipertensi dengan $\mathrm{OR}=1,98$; 95\% CI : 1,46-2,74. Proverawati (2010) menjelaskan bahwa dari perilaku sedentari yang berlebihan maka masyarakat berisiko untuk mengalami obesitas yang semakin besar risiko terjadinya hipertensi. Untuk perilaku sedentari, Jawa Barat menduduki peringkat empat tertinggi nasional proporsi penduduk yang melakukan perilaku sedentari lebih dari 6 jam (33,0\%). Angka ini melebihi angka nasional perilaku sedentari yakni sebesar 24,1\% (Kemenkes, 2013).

Perilaku mengkonsumsi alkohol dapat meningkatkan sintesis katekolamin, yang dapat memicu kenaikan tekanan darah (Suiraoka, 2012). Menurut Kenia (2013) dalam penelitiannya menjelaskan bahwa konsumsi alkohol berhubungan secara signifikan dengan kejadian hipertensi, nilai $\mathrm{p}=0,001 ; \mathrm{OR}=4,3 ; 95 \% \mathrm{CI}: 1.86-10.28$

Menurut Aditama (2015) bahwa dalam pencegahan hipertensi sebaiknya diawali dengan meningkatkan kesadaran masyarakat dan perubahan gaya hidup menuju arah yang lebih sehat. Menurut Putra (2013) dalam penelitiannya tentang perilaku pencegahan hipertensi kepada warga Desa Nyatnyono Kecamatan Ungaran Barat Kabupaten Semarang yaitu hanya sebanyak $24,6 \%$ yang memiliki perilaku pencegahan hipertensi primer dengan kategori baik. Menurut Bustan (2007) bahwa pencegahan primer pada penyakit hipertensi dilakukan dengan tujuan supaya orang sehat tetap sehat ataupun orang yang sehat tidak menjadi sakit. Pencegahan hipertensi diwujudkan dengan cara memodifikasi faktor risiko dengan cara memperkuat riwayat alamiah penyakit. 
JOURNAL OF NURSING PRACTICE AND EDUCATION VOL. 01 No. 01, DESEMBER 2020
Ciptaan disebarluaskan di bawah

Lisensi Creative Commons Atribusi-

NonKomersial-BerbagiSerupa 4.0 Internasional
Nugraha (2014) dalam penelitiannya menunjukkan terdapat sebanyak $32 \%$ responden masih memiliki sikap pencegahan terhadap hipertensi yang kurang. Sebagian besar keluarga memiliki persepsi yang salah terhadap kerja yang berlebihan dan merokok tidak menyebabkan hipertensi. Menurut Kurniati (2012) bahwa faktor-faktor yang mempengaruhi lemahnya upaya pencegahan hipertensi pada wanita usia produktif adalah pengetahuan yang kurang, keterbatasan paparan informasi, keterbatasan sarana prasarana dan kurangnya dukungan dari keluarga, tetangga dan petugas kesehatan.

Menurut Suddin (2013) bahwa perawat komunitas atau Puskesmas memberikan pelayanan kesehatan kepada individu, keluarga, kelompok/masyarakat berupa asuhan keperawatan kesehatan masyarakat yang utuh /holistik, komprehensif meliputi pemberian asuhan pada pencegahan tingkat pertama, tingkat kedua maupun tingkat ketiga. Dalam hal pencegahan hipertensi maka pelayanan kesehatan diberikan adalah pemeriksaan tekanan darah secara teratur kepada klien yang memiliki resiko hipertensi.

Menurut Friedman et al., (2010) bahwa faktor yang mempengaruhi dukungan keluarga adalah kelas tingkat ekonomi meliputi tingkat pendapatan atau pekerjaan, dan tingkat pendidikan. Purnawan (2008) menjelaskan bahwa faktor-faktor yang mempengaruhi dukungan keluarga terdiri dari usia pertumbuhan \& perkembangan keluarga, pendidikan atau tingkat pengetahuan keluarga, faktor emosional keluarga, faktor spiritual keluarga, praktik di keluarga, tingkat ekonomi keluarga, dan latar belakang budaya di keluarga. Menurut Amelia et al., (2014) dalam penelitiannya bahwa faktor yang paling mempengaruhi dukungan keluarga dalam diet penderita Diabetes Mellitus yaitu tingkat pengetahuan keluarga, praktik di keluarga, dan faktor tingkat tingkat ekonomi keluarga. Satya \& Putri (2015) dalam penelitiannya bahwa yang mempengaruhi dukungan keluarga dalam pemberian gizi anak Autis adalah tingkat pendidikan keluarga, tingkat pengetahuan keluarga, tingkat ekonomi, dan usia orang tua. Dari berbagai literatur tersebut maka peneliti tertarik ingin mengetahui apakah ada hubungan antara latar belakang budaya keluarga dengan dukungan keluarga dalam pencegahan primer hipertensi di wilayah kerja Puskesmas Windusengkahan. 
JOURNAL OF NURSING PRACTICE AND EDUCATION VOL. 01 No. 01, DESEMBER 2020
Ciptaan disebarluaskan di bawah

Lisensi Creative Commons Atribusi-

NonKomersial-BerbagiSerupa 4.0

Internasional.
Berdasarkan studi pendahuluan dengan menggunakan metode home visits kepada sepuluh keluarga yang memiliki anggota keluarga dengan risiko hipertensi di wilayah kerja Puskesmas Windusengkahan. Peneliti melakukan wawancara dengan memperoleh hasil bahwa empat keluarga merasa belum perlu memberikan dukungan pencegahan hipertensi karena belum merasakan gejala hipertensi pada anggota keluarganya, dua keluarga merasa perlu memberikan dukungan dalam pencegahan hipertensi kepada anggota keluarganya tapi merasa kesulitan dalam menyediakan waktu seperti rekreasi atau mengantar ke pelayanan kesehatan seperti Posyandu karena kesibukannya bekerja, dua keluarga merasa dukungan yang diberikan dalam pencegahan hipertensi masih kurang karena keluarga belum membiasakan dalam perilaku sehari-hari seperti jarang melakukan olahraga dan konsumsi gorengan berlebihan, serta dua keluarga yang merasa dukungan dalam pencegahan hipertensi diberikan sewajarnya saja karena urusan sakit dan sehat sudah diatur oleh tuhan.

\section{Metode Penelitian}

Desain penelitian ini adalah penelitian kuantitatif analitik korelasional dengan menggunakan regresi linier multivariat. Penelitian ini bertujuan untuk mengetahui hubungan antara latar belakang budaya keluarga dengan dukungan keluarga dalam pencegahan primer hipertensi di wilayah kerja Puskesmas Windusengkahan Kabupaten Kuningan.

Populasi dalam penelitian ini adalah seluruh keluarga yang memiliki anggota keluarga usia dewasa yang tidak menderita hipertensi memiliki riwayat keluarga dengan hipertensi dan memiliki minimal dua faktor dari risiko hipertensi seperti obesitas, merokok, usia > 55 tahun, atau konsumsi minuman keras. Teknik pengambilan sampel di setiap kelurahan dalam pada wilayah kerja Puskesmas Windusengkahan ini menggunakan proporsional random sampling yaitu dalam pengambilan anggota sampel pada setiap area penelitian berstrata secara proporsional serta tidak homogen. Jumlah sampel yang akan digunakan dalam penelitian ini adalah 132 orang sampel penelitian adalah anggota keluarga yang tinggal satu rumah di Wilayah Kerja Puskesmas Windusengkahan Kecamatan Windusengkahan Kabupaten Kuningan yang terdiri dari 4 kelurahan.

Instrument latar belakang budaya yang dipakai merujuk pada instrumen dari penelitian Amelia et al., (2014) dalam 
JOURNAL OF NURSING PRACTICE AND EDUCATION VOL. 01 NO. 01, DESEMBER 2020
Ciptaan disebarluaskan di bawah

Lisensi Creative Commons Atribusi-

NonKomersial-BerbagiSerupa 4.0 Internasional. penelitiannya bahwa faktor yang paling mempengaruhi dukungan keluarga dalam diet penderita Diabetes Mellitus yang sudah melalui tahap modifikasi oleh peneliti. Kuesioner latar belakang budaya terdiri dari 6 pertanyaan yang semuanya diukur dengan skala Likert (1-5) dengan nilai pernyataan yang favorable dan unfavorable.

Hasil uji validitas terhadap instrumen untuk pernyataan dukungan keluarga dalam pencegahan primer hipertensi dari 20 pernyataan mempunyai nilai hasil (0,467 sampai dengan 0,884$)$, untuk instrument faktor latar belakang budaya dari 6 pernyataan mempunyai nilai $r$ hasil $(0,416$ sampai dengan 0,730$)$. Dari semua instrument dapat dipastikan nilai $r$ tabel diatas atau lebih besar dari $\mathrm{r}$ tabel $(0,361)$ sehingga bisa disimpulkan valid. Setelah dilakukan uji statistik reliabilitas pada semua instrument didapatkan nilai alpha cronbach 0,762 sehingga kuesioner dikatakan reliabel.
Teknik analisis data terdiri dari uji univariat dan bivariat. Analisis univariat disajikan untuk menjelaskan gambaran karakteristik subjek penelitian. Variabel yang akan dianalisis adalah karakteristik responden, dukungan keluarga, dan latar belakang budaya keluarga. Analisis bivariat untuk mengetahui hubungan variabel hubungan dari latar belakang budaya keluarga dengan dukungan keluarga dalam pencegahan primer hipertensi menggunakan Pearson dengan tingkat kemaknaan $(\alpha=$ 0,05) dan pengolahan data menggunakan program komputer. Jika diketahui nilai $\rho$ value $<\alpha$ maka $\mathrm{H} 0$ ditolak dan apabila nilai $\rho$-value $>\alpha$ maka $\mathrm{H} 0$ gagal ditolak.

\section{Hasil Penelitian}

Analisis univariat menampilkan data distribusi frekuensi karakteristik responden. Karakteristik responden dalam penelitian ini terdiri dari usia, jenis kelamin, suku, pendidikan, pekerjaan, status pernikahan, dan agama.

\section{Tabel 1.1 Persentase karakteristik responden dengan risiko hipertensi di wilayah kerja}

Puskesmas Windusengkahan Tahun 2016 (n=132)

\begin{tabular}{lcc}
\hline \multicolumn{1}{c}{ Karakteristik Responden } & $\begin{array}{c}\text { Frekuensi } \\
(\mathbf{f})\end{array}$ & $\begin{array}{c}\text { Persentase } \\
(\boldsymbol{\%})\end{array}$ \\
\hline Kelompok Usia & & \\
$<20$ Tahun & 6 & 4,5 \\
$21-40$ Tahun & 81 & 60,9 \\
$41-60$ Tahun & 38 & 28,6 \\
$>60$ tahun & 6 & 4,5 \\
\hline Jenis Kelamin & & \\
Laki-laki & 82 & 61,7 \\
Perempuan & 50 & 37,6 \\
\hline
\end{tabular}




\begin{tabular}{lcc}
\hline Suku & & \\
Sunda & 93 & 69,9 \\
Jawa & 35 & 26,3 \\
Minang & 4 & 3 \\
\hline Pendidikan & & \\
SD & 6 & 4,5 \\
SMP & 22 & 16,5 \\
SMA & 74 & 55,6 \\
PT & 30 & 22,6 \\
\hline Pekerjaan & & \\
PNS & 11 & 8,3 \\
Swasta & 36 & 27,1 \\
Pedagang & 56 & 42,1 \\
Petani & 29 & 21,8 \\
\hline Status Pernikahan & & \\
Menikah & 103 & 77,4 \\
Belum Menikah & 29 & 21,8 \\
\hline Agama & & \\
Islam & 116 & 87,2 \\
Kristen & 16 & 12 \\
\hline
\end{tabular}

Berdasarkan tabel 1.1 diatas dapat digambarkan bahwa kondisi karakteristik demografi responden yang memiliki risiko hipertensi. Data tersebut menunjukkan bahwa usia responden atau anggota keluarga yang memiliki risiko hipertensi sebagian besar pada kelompok usia $21-40$ tahun $(60,9 \%)$. Jenis kelamin responden sebagian besar adalah laki-laki (61,7\%). Sebagian besar suku responden adalah suku sunda $(69,9 \%)$, pendidikan responden sebagian besar adalah SMA (55,6\%), pekerjaan responden sebagian besar adalah pedagang $(42,1 \%)$, status pernikahan responden sebagian besar adalah menikah $(77,4 \%)$, dan agama responden sebagian besar adalah islam $(87,2 \%)$.

Analisis bivariat bertujuan untuk melihat hubungan antara dua variabel yaitu variabel dependen dan variabel independen. Analisis bivariat menggunakan tabel silang dan korelasi pearson untuk menyoroti dan menganalisis perbedaan atau hubungan antara dua variabel. 
Tabel 1.2 Hubungan Latar Belakang Budaya Keluarga Dengan Dukungan Keluarga

Dalam Pencegahan Primer Hipertensi Di Wilayah Kerja Puskesmas

Windusengkahan

\begin{tabular}{l|c|c|c|c|c|c|c}
\hline \multirow{2}{*}{ Latar Belakang Budaya } & \multicolumn{4}{c|}{ Dukungan Keluarga } & \multicolumn{2}{c|}{ Jumlah } & \multirow{2}{*}{ P value } \\
\cline { 2 - 7 } & Mendukung & Kurang Mendukung & \multicolumn{2}{c}{} & \\
\cline { 2 - 7 } & $n$ & $\%$ & $n$ & 13.6 & 66 & 50 & \multirow{2}{*}{0,000} \\
\hline Mendukung & 48 & 36.4 & 18 & 31.8 & 66 & 50 & \\
\hline \multirow{2}{*}{ Kurang Mendukung } & 24 & 18.2 & 42 & & &
\end{tabular}

Persentase responden yang memiliki keluarga dengan latar belakang budaya mendukung lebih banyak merasakan dukungan keluarga dalam pencegahan hipertensi primer yaitu sebanyak 36,4\%. Dari hasil uji statistik didapatkan nilai $\mathrm{p}=$ 0,000 yang menunjukkan bahwa ada hubungan antara latar belakang budaya keluarga dengan dukungan keluarga dalam pencegahan primer hipertensi.

\section{Pembahasan}

\section{Univariat}

Berdasarkan analisis univariabel diperoleh hasil dari variabel dukungan keluarga bahwa responden yang memiliki risiko hipertensi yang sebagian besar merasakan dukungan keluarga sebanyak 72 responden (54,5\%). Menurut analisa peneliti bahwa lebih dari separuh jumlah responden merasakan dukungan keluarga dalam pencegahan primer. Tiga bentuk dukungan keluarga yang dirasakan responden dengan nilai tertinggi adalah keluarga mengingatkan responden untuk menjaga tekanan darahnya, keluarga menganjurkan untuk makan sayur dan buah setiap hari, dan keluarga menjaga kedekatan dan kehangatan untuk memotivasi responden menjaga tekanan darahnya (Lampiran). Sedangkan tiga bentuk dukungan keluarga yang dirasakan responden ada beberapa masih harus ditingkatkan karena memiliki nilai terendah yaitu bantuan keluarga dalam memecahkan setiap masalah dan kendala dalam hal menjaga tekanan darah responden, upaya keluarga dalam mengingatkan responden meluangkan waktu untuk rekreasi saat hari libur, dan upaya keluarga dalam menyediakan buah dan sayur yang dibutuhkan oleh responden (Lampiran).

$$
\text { Latar belakang budaya keluarga }
$$
hasil yang diperoleh adalah keluarga memiliki proporsi latar belakang budaya dengan proporsi seimbang $(50 \%)$ yaitu sebanyak 66 keluarga memiliki faktor latar 
JOURNAL OF NURSING PRACTICE AND EDUCATION VOL. 01 No. 01, DESEMBER 2020
Ciptaan disebarluaskan di bawah

Lisensi Creative Commons Atribusi-

NonKomersial-BerbagiSerupa 4.0

Internasional belakang budaya mendukung dan sisanya kurang mendukung dalam pencegahan primer hipertensi. Akumulasi nilai tertinggi dari latar belakang budaya adalah bahwa keluarga membatasi dalam aktivitas makan bersama di restoran "Cepat Saji" seperti KFC dan CFC, hal ini menunjukkan bahwa keluarga menyadari bahwa menu tersebut beresiko terhadap penyakit hipertensi dan membutuhkan biaya yang tinggi. Akumulasi nilai terendah dari latar belakang budaya keluarga yaitu kebiasaan keluarga menambahkan garam pada setiap masakan yang dihidangkan, hal ini menunjukkan bahwa keluarga masih kesulitan mengurangi kebiasaan pemakaian garam pada setiap menu masakan karena merasa masakan menjadi kurang sedap dirasakan oleh lidah bila tanpa dimasukkan garam (Lampiran).

Menurut analisa peneliti bahwa seimbangnya proporsi faktor latar belakang budaya keluarga menunjukkan bahwa keluarga belum mampu memodifikasi budaya yang sudah sejak turun temurun dari mana budaya tersebut berhubungan dengan pemeliharaan kesehatan keluarga khususnya pencegahan primer hipertensi. Menurut analisis peneliti disebabkan karena keluarga responden sebagian besar memiliki karakteristik suku sunda yang memiliki budaya atau kebiasaan mengkonsumsi makanan seperti ikan asin atau makanan yang digoreng. Walaupun sebagian besar keluarga berasal dari suku sunda tetapi tingkat pendidikan mempengaruhi pola hidup sehat keluarga dengan adanya paparan informasi tentang kesehatan khususnya hipertensi sehingga ada sebagian keluarga mampu memodifikasi budaya atau kebiasaan yang mendukung dalam pemeliharaan kesehatan khususnya pencegahan primer hipertensi.

\section{Bivariat}

Hubungan Latar Belakang Budaya Keluarga Dengan Dukungan Keluarga Dalam Pencegahan Primer Hipertensi

Berdasarkan hasil analisis pada responden yaitu anggota keluarga yang memiliki risiko hipertensi beserta keluarganya didapatkan hasil bahwa sebagian besar sebanyak 48 responden $(36,4 \%)$ merasakan dukungan keluarga dalam pencegahan primer hipertensi yang sangat tinggi dan memiliki keluarga dengan latar belakang yang mendukung dalam pencegahan primer hipertensi. Pada latar belakang budaya dengan dukungan keluarga sangat tinggi. Secara statistik latar belakang budaya keluarga memiliki hubungan yang signifikan terhadap dukungan keluarga yang dirasakan oleh 
JOURNAL OF NURSING PRACTICE AND EDUCATION VOL. 01 NO. 01, DESEMBER 2020
Ciptaan disebarluaskan di bawah

Lisensi Creative Commons Atribusi-

NonKomersial-BerbagiSerupa 4.0 Internasional. responden, hal ini dapat dilihat dari $\mathrm{p}$ value $=0,000$ yang menunjukan bahwa ada hubungan antara latar belakang budaya keluarga dengan dukungan keluarga dalam pencegahan primer hipertensi yang dirasakan responden. Winkelman (2009) menjelaskan bahwa latar belakang budaya keluarga berpengaruh terhadap perilaku kesehatan, keyakinan, dan nilai kesehatan dalam keluarga. Menurut Purnawan (2008) bahwa latar belakang budaya mempengaruhi keyakinan, nilai dan kebiasaan individu dalam memberikan dukungan termasuk cara pelaksanaan kesehatan pribadi khususnya dalam pencegahan hipertensi. Menurut Setiadi (2008) bahwa salah satu hambatan pada keluarga adalah kepercayaan budaya yang tidak menunjang kesehatan, seperti kepercayaan bahwa perilaku tertentu yang merupakan faktor pencetus hipertensi dianggap tidak membahayakan sehingga tidak dilakukan pencegahan sejak dini.

\section{Kesimpulan}

Dari penelitian ini memperoleh hasil bahwa ada hubungan antara latar belakang budaya keluarga dengan dukungan keluarga dalam pencegahan primer hipertensi yang dirasakan responden $(\mathrm{p}$ value $=0,000)$, maka dari itu ketika seorang perawat keluarga melakukan pembinaan pada klien dalam pencegahan primer hipertensi maka sebaiknya memperhatikan latar belakang budaya keluarga supaya turut mendukung dalam pencegahan primer hipertensi.

\section{Daftar Pustaka}

Acelajado, M. C. (2010). Optimal management of hypertension in elderly patients. Integrated Blood Pressure Control, 3, 145.

Aditama, T. Y. (2015). Masalah Hipertensi di Indonesia.

Ahmad Husain Asdie, S.-K. (2009). FaktorFaktor Kejadian Hipertensi Pada Perempuan Usia 20-50 Tahun di Kota Bengkulu. Yogyakarta : Universitas Gadjah Mada.

Amelia, M., Nurchayati, S., \& Elita, V. (2014). Analisis Faktor-Faktor Yang Mempengaruhi Keluarga Untuk Memberikan Dukungan Kepada Klien Diabetes Mellitus Dalam Menjalani Diet. Riau University.

Badan Penelitian Dan Pengembangan Kesehatan. (2014). Penyebab Kematian Tertinggi Di Indonesia (diakses 3 Maret 2015).

Badan Penyelenggara Jaminan Sosial. (2015). Panduan Praktis Program Penyelenggara Penyakit Kronis. Jakarta : BPJS Kesehatan.

Bhadoria, A. S., Kasar, P. K., Toppo, N. A., Bhadoria, P., Pradhan, S., \& Kabirpanthi, V. (2014). Prevalence of hypertension and associated cardiovascular risk factors in Central India. Journal of Family \& Community Medicine, 21(1), 29. 
JOURNAL OF NURSING PRACTICE AND EDUCATION

VOL. 01 NO. 01, DESEMBER 2020
Ciptaan disebarluaskan di bawah

Lisensi Creative Commons Atribusi-

NonKomersial-BerbagiSerupa 4.0 Internasional.
Bustan, M. N. (2007). Epidemiologi Penyakit Tidak Menular. Jakarta: Rineka Cipta, 221.

Friedman, M. M., Bowden, V. R., \& Jones, E. G. (2010). Buku Ajar Keperawatan Keluarga: Riset, Teori, dan Praktek. Jakarta: EGC, 5-6.

Gu, J., Zhang, X.-J., Wang, T.-H., Zhang, Y., \& Chen, Q. (2014). Hypertension knowledge, awareness, and selfmanagement behaviors affect hypertension control: a communitybased study in Xuhui District, Shanghai, China. Cardiology, 127(2), 96-104.

Hashani, V., Roshi, E., \& Burazeri, G. (2014). Correlates of Hypertension Among Adult Men and Women In Kosovo. Materia Socio-Medica, 26(3), 213.

Huang, S., Chen, Y., Zhou, J., \& Wang, J. (2014). Use of family member-based supervision in the management of patients with hypertension in rural China. Patient Preference and Adherence, 8, 1035.

Kapriana, M. T., \& Sulchan, M. (2012). Asupan Tinggi Lemak Dan Aktivitas Olahraga Sebagai Faktor Risiko Terjadinya Hipertensi Obesitik Pada Remaja Awal. Diponegoro University.

Kemenkes, R. (2013). Profil Kesehatan Indonesia 2013.

Kenia, N. M. dan D. T. (2013). Pengaruh Relaksasi (Aromaterapi Mawar) Terhadap Perubahan Tekanan Darah Pada Lansia Hipertensi. Kediri : STIKes RS. Baptis Kediri.
Kurniati, D. P. Y., \& Mkm, D. P. Y. K. (2012). Perilaku Berolahraga dalam Upaya Pencegahan Hipertensi pada Wanita Usia Produktif di Pancoran Mas, Depok, Jawa Barat. Archive of Community Health, 1(2).

Martiningsih. (2011). Analisis faktor-faktor yang berhubungan dengan terjadinya hipertensi primer pada pasien di Poliklinik Penyakit Dalam RSUD Bima ditinjau dari perspektif keperawatan self-care Orem. Tesis. Universitas Indonesia.

Muliyati, H., Syam, A., \& Sirajuddin, S. (2011). Hubungan Pola Konsumsi Natrium Dan Kalium Serta Aktivitas Fisik Dengan Kejadian Hipertensi Pada Pasien Rawat Jalan di RSUP dr. Wahidin Sudirohusodo Makassar. Media Gizi Masyarakat Indonesia, 1(1), 46-51.

Nugraha, B. K. A. R. I. (2014). Hubungan Tingkat Pengetahuan Keluarga Dengan Sikap Pencegahan Komplikasi Pada Pasien Hipertensi Di Wilayah Kerja Puskesmas Sangkrah Surakarta. Universitas Muhammadiyah Surakarta.

Osamor, P. E., Owumi, B. E. (2011). Factors Associated with Treatment Compliance in Hypertension in Southwest Nigeria. Nigeria: Journal of Health Population Nutrition.

Profil Puskesmas Windusengkahan. (2014). Laporan 10 Besar Penyakit di Puskesmas Windusengkahan Kabupaten Kuningan tahun 2014. Puskesmas Windusengkahan, Kabupaten Kuningan.

Proverawati, A. (2010). Obesitas dan Gangguan Perilaku Makan Pada 
JOURNAL OF NURSING PRACTICE AND EDUCATION

VOL. 01 NO. 01, DESEMBER 2020

Remaja. Yogyakarta: Nuha Medika, 112.

Purnawan, I. (2008). Dukungan Suami dan Keluarga. Jakarta: Salemba Medika.

Putra, P. (2013). Hubungan Pengetahuan Tentang Hipertensi Dengan Perilaku Pencegahan Primer Di Desa Nyatnyono Kecamatan Ungaran Barat. Jurnal STIKES Ngudi Waluyo Ungaran.

Qin, Y., Melse-Boonstra, A., Pan, X., Zhao, J., Yuan, B., Dai, Y., Zhou, M., Geleijnse, J. M., Kok, F. J., \& Shi, Z. (2014). Association of dietary pattern and body weight with blood pressure in Jiangsu Province, China. BMC Public Health, 14(1), 948.

Rahayu. (2012). Faktor Resiko Hipertensi Pada Masyarakat Rw 01 Srengseng Sawah, Kecamatan Jagakarsa, Kota Jakarta Selatan. Depok: Universitas Indonesia.

Riset Kesehatan Dasar (Riskesdas). (2013). Riset Kesehatan Dasar (Riskesdas). http://www.litbang.depkes.go.id/sites/ Riskesdas 2013. (diakses 1 September 2015)

Satya, D. Putri, A. (2015). Factors Which Associated With Family Support to Provision Autism Nutrition Gift in Autism Foundation Center "CAKRA" Pucang Jajar Surabaya. Jurnal Keperawatan STIKes Hang Tuah Surabaya.

Setiadi. (2008). Konsep dan Proses Keperawatan Keluarga. Yogyakarta: Graha Ilmu.

Suddin. A. (2013). Hubungan Pelaksanaan
Ciptaan disebarluaskan di bawah

Lisensi Creative Commons Atribusi-

NonKomersial-BerbagiSerupa 4.0

Internasional.

Peran Perawat Keperawatan

Kesehatan Masyarakat Dengan Mutu

Pelayanan Di Puskesmas Kabupaten

Takalar Tahun 2013. Tesis.

Universitas Hasanudin Makassar.

Sugiharto, A. (2007). Faktor-faktor risiko hipertensi grade II pada masyarakat (studi kasus di kabupaten Karanganyar). program Pascasarjana Universitas Diponegoro.

Suhadi. (2011). Analisis Faktor-Faktor Yang Mempengaruhi Kepatuhan Lansia Dalam Perawatan Hipertensi Di Wilayah Puskesmas Srondol Kota Semarang. Tesis. Universitas Indonesia.

Suiraoka, I. P. (2012). Penyakit degeneratif. Yogyakarta: Nuha Medika, 45-51.

Susilo, Yekti, \& Ari, W. (2011). Cara Jitu Mengatasi Hipertensi. Yogyakarta: Andi.

Wahiduddin, Hasrin, M. \& R. (2013). Faktor Risiko Kejadian Hipertensi di Kecamatan Bangkala Kabupaten Jeneponto Sulawesi Selatan.

WHO. (2012). World Health Day 2013 : Measure Your Blood Pressure, Reduce Your Risk.

Winkelman, M. (2009). Culture and Health: Applying Medical Anthropology. John Wiley \& Sons.

Wu, E.-L., Chien, I.-C., Lin, C.-H., Chou, Y.-J., \& Chou, P. (2012). Increased risk of hypertension in patients with major depressive disorder: a population-based study. Journal of Psychosomatic Research, 73(3), 169174. 